\title{
CALVINISTIC OUTLOOK
}

\section{OUTLINE OF THE INSTITUTE FOR THE ADVANCEMENT OF CALVINISM.}

We are pleased to comply with the request of the Editor to sketch the I A C activities for the first English issue of "Koers". Although still young and limited in its possibilities, this institute has already become a significant landmark of Calvinistic thought.

\section{CHARACTER:}

The I A C was established in 1966 (as the successor to the previous "Calvinistic Foundation" founded in 1962) as an interfaculty institute of the University of Potchefstroom for Christian Higher Education. All the faculties of the University are represented on the Council of the I A C. Up to June 1974 pioneering work was done by its part-time director Professor S C W Duvenage. From the second semester of 1974, a new centre was opened, and a full-time director and secretary took over the steadily increasing volume of work of the Institute.

\section{AIM:}

The I A C tries to render service in the kingdom of God by way of study, research and publications on Calvin and Calvinism. Our propagation of the Calvinistic life and world view is founded on the firm conviction that this life and world view is, by nature of its absolute obedience to Scripture, the most consistent of all Christian points of view.

\section{WORKING PROCEDURE:}

The programme of activities of the I A Chas included the following over the last few years:

3.1 PAMPHLET SERIES ON IMPORTANT ISSUES:

Articles on topical matters, composed and duly elucidated from a Calvinistic-Biblical point of view by authorities in their respective fields, are circulated monthly in pamphlet form. Eighty-five of these 
pamphlets on various topics have thus far been published in Afrikaans. The I A C Council plans to issue some of them in English in future. At present about 3,500 of these studies are sent to recipients in South Africa and also in various other countries, free of charge.

The following list of pamphlets, published during 1974 gives an impression of the variety of problems dealt with:

No. 77: The normative versus the neutral approach in art - Prof P D van der Walt.

No. 78: Compulsory service and conscientious objection against military service (by the Jehowa Witnesses) - Col Dr J F Potgieter and Capl (Rev) J P Munnik.

No. 79: A few practical and ethical considerations about economical motivations - Prof W J Venter.

No. 80: Natural science and culture with special reference to the worldview of the natural sciences - Prof P J Botha.

No. 81: Some considerations about freedom of the press Prof B Duvenage.

No. 82: The struggle between Roman Catholics and Protestants in Ireland - Dr P de Klerk.

No. 83: The right of privacy - Mr L M du Plessis.

No. 84: Non-White trade unions in South Africa - Mr W N Coetzee.

No. 85: Focal points regarding certain medical-ethical issues - Dr H D Brandt.

No. 86: Boxing: a permissible sport? - Prof W Putter.

A complete list of pamphlets published before 1974 is available from our office. 
3.2 BROCHURES:

We have also published the following brochures: Die gesag van die Heilige Skrif (The authority of Scripture) by Prof S C W Duvenage; Toneel, film en radio (Dramatic art, film and radio) by Dr A J van Rooy; Blanke volksontwikkeling in die lig van die Calvinisme (Development of the whites in the light of Calvinism) by Prof J H Coetzee; Die Calvinis en die kuns (The Calvinist and art) by Prof P D van der Walt; Calvijns betekenis in onze tijd (Calvin's significance for our time) by Prof K Runia and Menseregte (Hu man rights) by Prof J D van der Vyver.

In preparation we have at the moment brochures on the following topics: The philosophy of the idea of creation by the well-known philosopher Prof H G Stoker himself; The energy crisis by six different authors dealing with different aspects; The next step (a book by Dr A J van Rooy and others reflecting on the best political structure for Southern Africa when all the Bantu nations have become totally independent.)

\subsection{LARGER WORKS:}

The I A C aspires to publish more comprehensive works at least every five years. In 1969, it issued (as a contribution to the centenary celebration of the University of Potchefstroom and the Theological School of the Reformed Church in S A) a publication Die atoomeeu -,, in Ulig". (The atomic age in the light of the Word of God). Following this "Festschrift" of about thirty articles, written by Calvinists throughout the world, there appeared recently the volume Reformasie en Revolusie (Reformation and Revolution) comprising twenty-four contributions dealing with the different facets of revolution in the contemporary world from a reformational point of view.

\subsection{CALVINIANA RESEARCH:}

In addition to the publications mentioned above, we commenced a series of Calvin-causeries in 1973. Two of these appeared in print viz., Calvin's view on Scripture and Calvin on state and law. 
These causeries are annotated bibliographies of books and articles available in the Ferdinand Postma Library of the University of Potchefstroom on the subjects mentioned. The idea is to evaluate this material on a specialized subject for a broader spectrum of people and to evoke the interest of scholars on these topics. The range of material available may not be too wide at present, but as time passes, and the research material accumulated grows, the scope will increase and these causeries will become more indispensable to students and interested readers.

Apart from the two causeries mentioned a third one comprises a bibliography of books and articles on Calvin and Calvinism which where issued in South Africa or by South Africans. This valuable bibliography contains about 250 titles of which only about six have appeared in the well-known bibliography of Niesel published in 1959.

According to schedule Calvin causeries on the following subjects will appear in the near future: Calvin's point of view of Christian ethics, music, the relationship between church and state, education, ecclesiastical ecumenical relationships, church government and church discipline, pastoral care, culture, economics, science, his attitude towards missionary work, ecclesiastical councils, his soteriological viewpoint, doctrine about God, and his anthropology.

The publication of these causeries became possible as a first result of our bibliographical research by Dr D. Kempff on Calviniana in about sixty libraries of ten overseas countries. ') Already in the press is an international Calviniana Bibliography (1959-1974). As the third extensive bibliography of this kind, it will be a companion to the work done by A. Erichson: Bibliographia Calviniana (1900) and W. Niesel: Calvin Bibliographie 1901 - 1959. It will contain not only new material subsequent to $1958 / 1959$, but will also include items which have been omitted in the two previous 
bibliographies mentioned above as well as in smaller bibliographical studies (published after the one by Niesel in 1959) such as the following: $R$. Nicole: Some notes towards a bibliography of John Calvin.Gordon Review. 5: 174-181, 1959; 6: 21-28, 1960; L.R. de Koster: Living themes in the thought of John Calvin. A bibliographical study (1964); Brussels, Centre National de Bibliographie. Les Bibliographies I: Jean Calvin (1964); Rowe, K.E.: Calvin Bibliography (1967); Fraenkel, P.: Petit supplément aux bibliographies calviniennes, 1901-1963. Bibliotheque d' Humanisme et Renaissance, 33(2): 385-313, 1971; Tylenda, J.N. Calvin Bibliography. Calvin Theological Journal, 6(2): 156-193, 1971; De Klerk, P.: Calvin Bibliography Calvin Theological Journal, 7(2): 221-250, Nov. 1972; 9(1): 38-73, April 1974.

The following table of contents of the CalvinianaBibliography 1959 - 1974 clearly indicates the vast amount of material it includes (about 3,000 titles in total!) Chapter I: Calvin's own works; Chapter II: Works about Calvin: general; Chapterlll: Works about Calvin: Various subjects; Chapter IV: Calvinism; section 1: General; section 2: Various reformers; section 3: Countries, matters and opponents.

4. THE IMPACT OF CALVINISM ON SOUTH AFRICA: We regard the study of the original sources as of the utmost importance to keep our research authentic. In an extensive research program, which will be carried out during the next decade, we will try to ascertain the impact of Calvinism on the South African society. In this project the links between South African and European Calvinism will be traced. In addition to the Reformational heritage of the 16th Century, its background will be studied as far back as the PreReformation, the Late Mediaeval and even the Patristic period. 
The I A C does not aim to revive, with the help of the historical research in an anachronistic way, the past. Because of many possible deviations during four centuries of development of Calvinistic thought it is important to get to the promogenitor. The idea is not to canonise the thought of Calvin but to build on the firm foundation of his ideas which clearly echoed Biblical revelation. In this way the I A C endeavours by means of unswerving loyalty to Scripture to be a power station of the Calvinistic life and world view in the contemporary world.

The following information about this project on the impact of Calvinism on the South African society is interesting. The assumption behind this research program is that it was exactly the Calvinistic life and world view which moulded the Afrikaans speaking White people to become what they are today. This is the secret behind many viewpoints and attitudes of the Afrikaners. The Afrikaners gave a typical cachet to Calvinism.

The idea is to ascertain exactly what the influence of this Afrikaner-Calvinism was on the different areas of life. With the results thus acquired it will also be possible to outline a prognosis. In a creative modern way a plan of action for the future should be worked out.

Schematically we intend to study the following:

1) Reflection on the Fundamental principles of Calvinism which will serve as a basis for the rest of the program.

2) Historical approach on the backgrounds of our Calvinistic heritage in Europe.

3) The links between European and South African Calvinism at different phases of contact, $\theta \mathrm{g}$, during the time of Jan van Riebeeck (1652), the French Huguenots (1688), the Scottich Calvinists (1820), the Dutch Teachers (1880 - 1900) and also during the 20th Century.

4) The impact of Calvinism on different spheres of life. 
(a) Ecclesiastical sphere.

(b) Education: schools, colleges, universities, and also different associations which played an important role in the propagation of the idea of Christian education at all levels. A special study will therefore be made of the idea of a Christian scientific endeavour in general as well as in particular sciences.

c) Politics in theory and practice.

d) Married and family life.

e) Ethical relationships.

f) Cultural organisations.

g) The world of art.

h) Sport, recreation and entertainment.

i) Judicature.

j) Technology.

k) Economical life (including labour, industry and finance).

1) Communication (press, radio, film and television).

$\mathrm{m})$ The impact of Calvinism on people of various other races and languages.

The above bird's eye view of the project gives an idea of the enormous amount of work to be done. The I A C is privileged that, as an interfaculty institute, it has the cooperation and support of the different faculties and departments at the Potchefstroom University for Christian Higher Education. Post graduate students in different subjects will be encouraged to write master's and doctor's theses on aspects of the project. As the research programme unfolds, results will be disseminated by way of publications and at the end a comprehensive survey of different volumes will be printed.

5. SPIRITUAL ARSENAL:

A complete catalogue of all the books and articles on Calvin and Calvinism available in different South African libraries is kept in the I A C Centre.

Furthermore a continuous effort is made to enlarge the existing Calviniana collection (already of a high 
standard) at the Ferdinand Postma Library of the University of Potchefstroom. The collection consists of inter alia the following different categories: Works of Calvin himself in the original (Latin or French) as well as in translation (English, German and Dutch); works about Calvin and the development of his thought; works dealing with Calvin's place in the history of Western civilization and church; works tracing the influence of Calvin's thought and work; works on Calvinism as a philosophy of life.

The Institute does not merely try to keep up to date with the latest publications, but it also tries to collect as much of the older stuff as possible. We are especially interested to enlarge our existing collection of doctor's and masters theses.

With such a well equipped arsenal the I A C can become a stronghold of Calvinistic thought and action in future.

\section{INTERNATIONAL CONGRESS}

The University of Potchefstroom is at present planning an international conference on all aspects of tertiary education. Different institutions (universities, colleges, theological seminaries and organisations) practising science from a similar Christian point of view as the Uni versity of Potchefstroom for Christian Higher Education, as well as like-minded thinkers from elsewhere will be invited to partake in this meeting scheduled for October 1975. In this way the University of Potchefstroom and the I A C - which will aid the University in this significant effort towards international co-operation hope to serve the kingdom of God on the scientific level.

\section{INTERNATIONAL CO-OPERATION NEEDED:}

The I A $C$ has already established contact with various similar institutions and organisations throughout the world and it will be glad to get in touch with institutions with the same line of action in future. We will be very willing to exchange publications on a mutual basis. 
News about study projects and results will be appreciated.

B J van der Walt,

October 1974

Director I A C,

$\mathrm{P} U$ for $\mathrm{CH} \mathrm{E}$,

POTCHEFSTROOM 2520,

South Africa. 


\section{REFERENCES}

1. The following libraries were visited personally.

$\begin{array}{lll}\text { ROME: } & \begin{array}{l}\text { Vatican, } \\ \text { University, } \\ \text { Institute; }\end{array} & \begin{array}{c}\text { Gregoriano } \\ \text { Waldensian }\end{array} \\ \text { VIENNA: } & \text { National, University; } \\ \text { GENEVE: } & \begin{array}{l}\text { Reformation } \\ \text { University; }\end{array} \\ \text { STAATSBURG: } & \begin{array}{l}\text { Theological } \\ \text { (Protestant), City/University, } \\ \text { Ecumenical Centre; }\end{array}\end{array}$

PARIS:

National, Free Protestant Faculty, Protestant Library;

HOLLAND:

Royal (Den Hague), Leiden University, City University, Amsterdam, Free University, Amsterdam, Theological School (Oudestreet, Kampen,) Theological School, (Broederstreet, Kampen,) Theological School, Christ. Ref. Church, (Appeldoorn);

LONDON:

British Museum, University, Huguenot Society, University College;

EDINBURGH:

Evangelical Society, National Library, Free Church College, New College;

BOSTON:

Harvard, Divinity School;

NEW HAVEN:

Yale, Divinity School; 
NEW YORK:

Columbia University, Union Theological Seminary, New York University;

PHILADELPHIA,

Penn.: University of Pennsylvania, Westminster Theol. Seminary;

WASHINGTON, DC.: $\quad$ Library of Congress;

RICHMOND, Virg.: Union Theological Seminary;

CHICAGO: University (Joseph Regenstein), Divinity School (Swift Library), Theol. Seminary (Hammond Library), De Paul University;

MADISON, Wisc.: $\quad$ University;

GRAND RAPIDS: Calvin Theological Seminary;

TUBINGEN: $\quad$ University Library

The contents of the following libraries was ascertained by way of correspondence.

KIEL: University;

MONTRE AL: $\quad$ McGill University;

DALLAS, Tex.: $\quad$ Southern Methodist Univ.;

PASSADENA, Cal.: $\quad$ Fuller Theol. Semin.;

MADISON, N J: $\quad$ Drew University;

DURHAM, N C: $\quad$ Duke Univ. Divinity School Lib.;

NASHVILLE, Tenn.: Vanderbilt University; 
LOUISVILLE, Ken.: $\quad$ Southern Baptist Theol. Sem.;

PITTSBURGH, Penn.: $\quad$ Pittsburgh Theol. Sem.;

WASHINGTON, DC.: Catholic Univ.;

FORT WORTH, Tex.: $\quad$ South Western Baptist Theol. Sem.;

FRANKFURT-AM-MAIN: Deutsche Bibliothek;

GöTTINGEN: Niedersachsische City and Univ. Library;

HOUSTON, Tex.: $\quad$ Rice University;

LAUSANNE: University Library. 